\title{
A Study of Impact of Cashless Transaction on Society Using Statistical Methods
}

\author{
Prakash S. Chougule \\ Associate Professor \\ Suresh T. Salunkhe \\ Principal
}

\author{
Tejaswi S. Kurane \\ Assistant Professor \\ Puja A. Pawar \\ Research Student
}

R. C. Shahu College Kolhapur-416005. (MS), India

\begin{abstract}
A cashless society describes an economic state whereby financial transaction are not conduced with money in the form of physical banknotes or coins but rather though the transfer of digital information (usually an electronic representation of money) between the transacting parties. Cashless society have existed based on barter and other methods of exchange, and cashless transactions have also become possible using digital currencies such as bit coins. Cashless India is a mission launched by the government of India led by prime minister Narendramodi to reduce dependency of Indian economy on cash and to bring hoards of stashed black money lying unused into the banking system. The country embarked upon this transition to a cashless economy when the government took the revolutionary step of demonetization of old currency notes such as Rs.500 and Rs.1000 on November 8, 2016. Different activities needed to be planned in all the point of view for migration to cashless society and digital India to achieve the aim of payment and settlement system of India: Vision 2018.
\end{abstract}

Keywords:- Cashless, Transaction, Digital, Bit coins, ANOVA, P-Value, Level of significance.

\section{INTRODUCTION}

Cashless policy will also reduce cash related corruption and attract more foreign investors to the country. It is expected that its impact will be felt in modernization of payment system, Reduction in the cost of banking service, Reduction in high security and safety risk and also curb banking related corruption.

The word cashless transaction means stopping the people to use money through hands and making them to use it through electronic media or credit cards bank transfers, checks etc. and payment system such as immediate and payments service IMPS, NEFS, RTGS in India.

In India cash is expensive (every year RBI spent and Rs 32 billion on printing currency) and the no of people use in tax evasion black money etc. The government is decided to increase tax revenues so cashless economy mom dates all citizens to have bank account so we are decided to study what is the impact of cashless transaction on society.
Cashless economy is an economy in which all types of transaction are carried out through digital means it includes E- banking ,debit card, credit card ,card swipe, machines and digital wallets cashless economy increases the speed at which the money is transferred from one person to another and a large part of population is still outside the scope of net banking like use of credit card or debit card making transaction using mobile phone and using the internet to pay bills they are not in a position to reduce its dependence on cash .the government of India followed a detail criterion by first SIT on black money then Jan -dhanyojana which are followed by tracking on foreign account and money, when demonetization is done then people have no money to buy some commodities so there is cashless system evolved. We study that how many people use the cashless transaction also find out mostly used the mode of cashless transaction amongst our society.

\section{LITERATURE REVIEW}

Ashish Das, and Rakhi Agarwal, (2010) suggested that the cash payment is an expensive proposition to the government and so the nation must step towards the cashless payment system which reduced the track transactions, currency management cost, eliminates tax avoidance, fraud etc.

Alvares, Cliford (2009) have explained in the report that many fake notes are going undetected and the battle against the fake note is harder.

$>$ Annamalai, S. and Muthu R. Iiakkuvan (2008) studied the future of plastic money in retail transaction. The growth of the debit and credit cards in retail transactions were projected by them in their study. The popularity leading growth factors, the obstacles faced by the banks, future and scope of the plastic money were explained in their study.

> Jain, P.M (2006) studied about the e-payments and ebanking. With the help of technological advancement, rapid payment options and other features, there will be an optimal use of funds for banks, other financial institutions, and business houses and so on. He also elaborated the importance and need for e-payments and modes of e-payments and communication networks 
* Objective

- To study the opinion about security about online banking in urban and rural area

- To study the effect of demonetization on online banking in urban and rural area

- To study awareness about plastic money in urban and rural area
- To study the relationship between online banking users and sex in urban and rural area

- To study association between online banking users and area

- To study whether there is significance difference between monthly transaction of online banking in urban and rural area

\section{METHOD OF DATA COLLECTION}

In this article, we have collected data from 300 users in which some are from urban area and some from rural area

Statistical tools used: 1) Graphical Representation 2) Testing of Hypothesis

Software Used: MS - Excel, MS - Word, Libre Office

Users of Online Banking in Urban \& Rural Area:

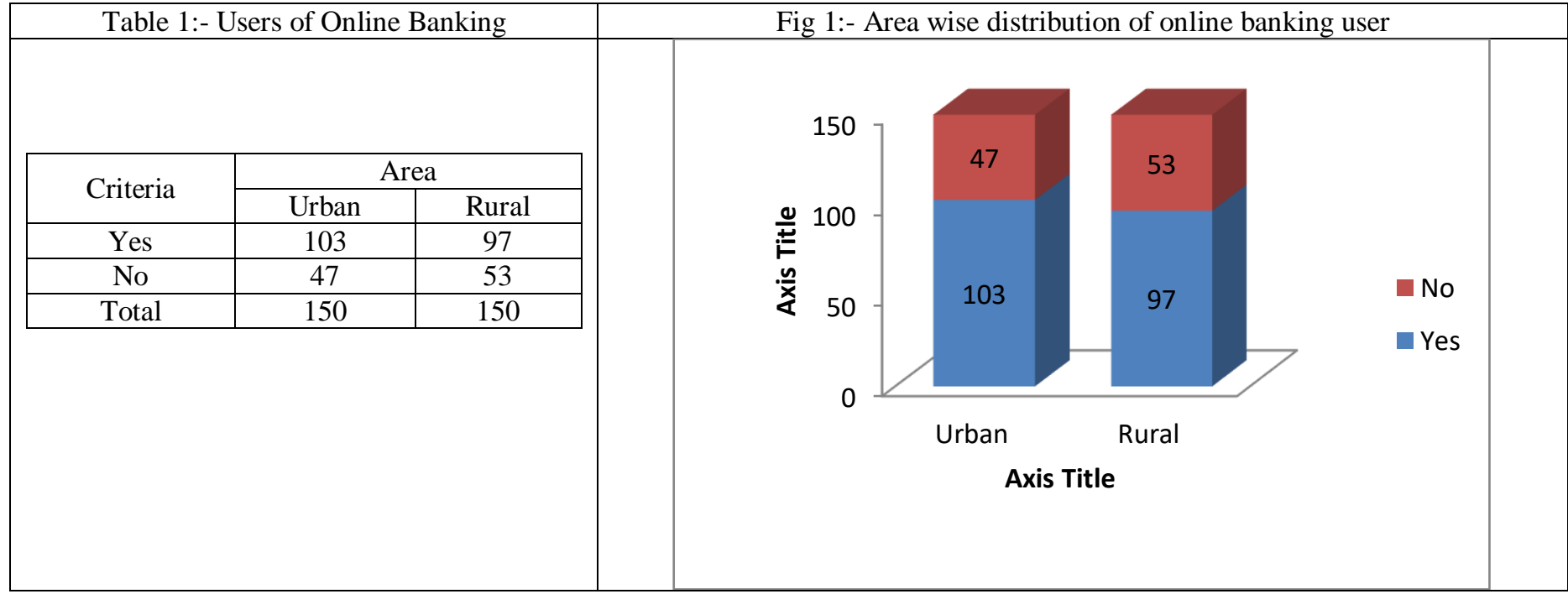

Opinion about Security of Online Banking in Urban \& Rural Area:

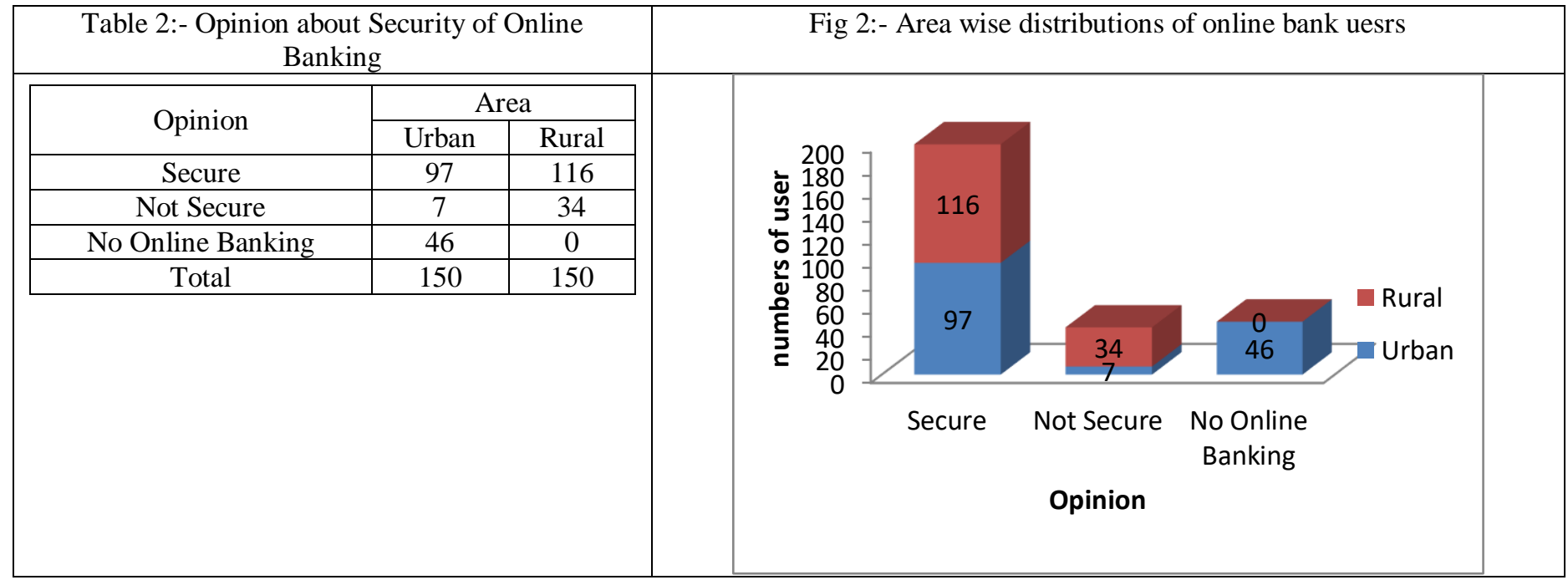


Effect of Demonetization on Online Banking in Urban \& Rural Area:

\begin{tabular}{|c|c|c|c|c|c|}
\hline \multicolumn{2}{|c|}{ Table 3:- Effect of Demonetization } & \multicolumn{3}{c|}{ Fig 3:- Area wise distributions of Effect of Demonetization on Online } \\
Banking
\end{tabular}

Purpose of Online Banking in Urban and Rural Area:

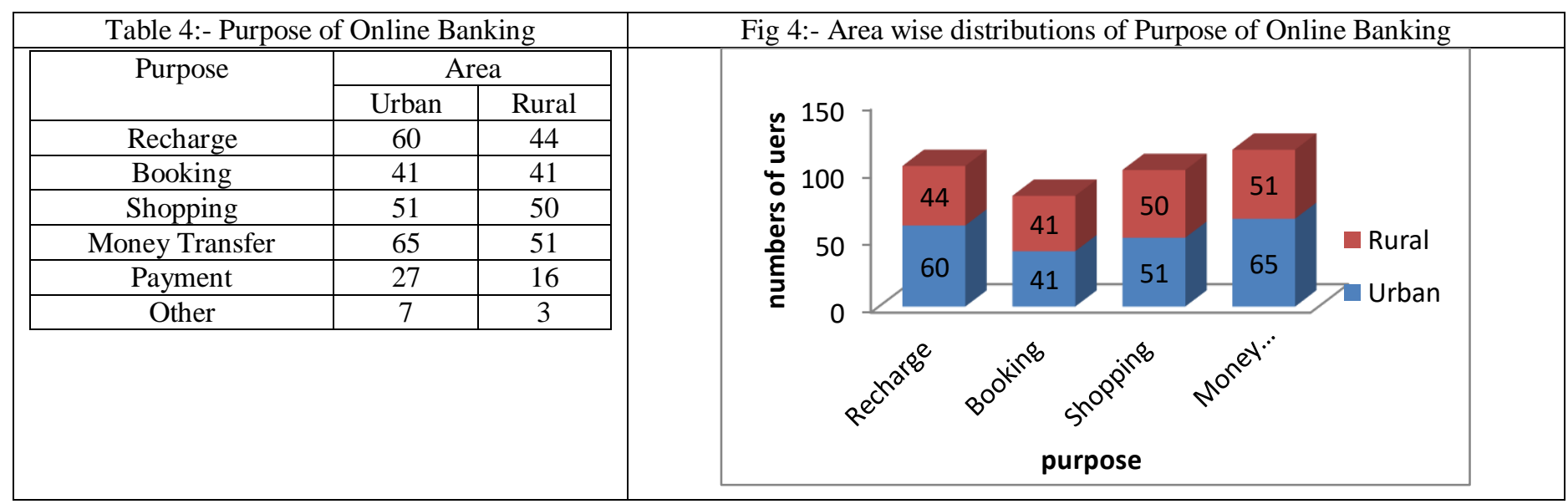

Awareness about plastic money in Urban \& Rural Area:

\begin{tabular}{|c|c|c|}
\hline \multicolumn{3}{|c|}{ Table 5:- Awareness About Plastic Money } \\
\hline \multirow{2}{*}{ Plastic Money } & \multicolumn{2}{|c|}{ Area } \\
\cline { 2 - 3 } & Urban & Rural \\
\hline Credit Card & 21 & 13 \\
\hline Debit Card & 45 & 42 \\
\hline ATM Card & 72 & 66 \\
\hline Visa Card & 2 & 3 \\
\hline Master card & 3 & 6 \\
\hline All cards & 12 & 16 \\
\hline No card & 3 & 4 \\
\hline
\end{tabular}

Fig 5:- Area wise distributions of Awareness About Plastic Money

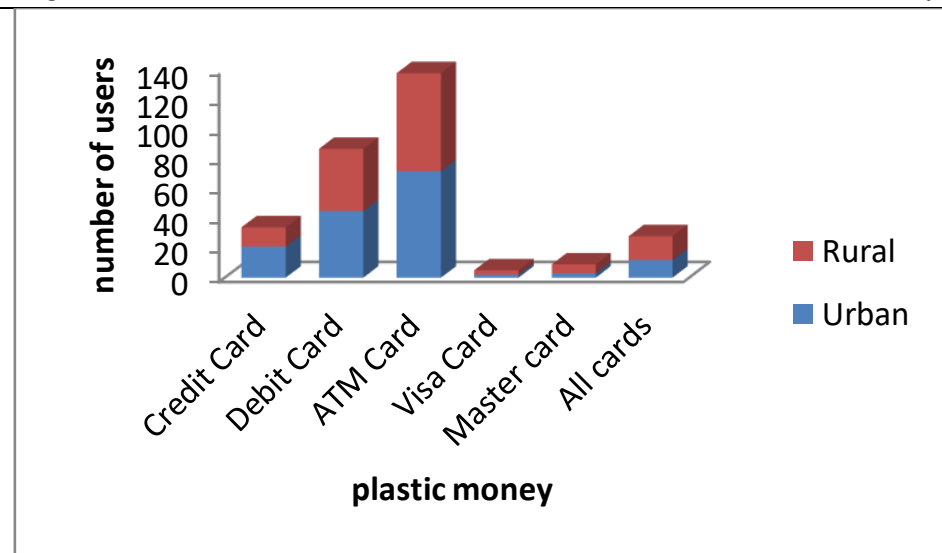


Awareness about Plastic Money in Urban\& Rural Area (Gender wise):

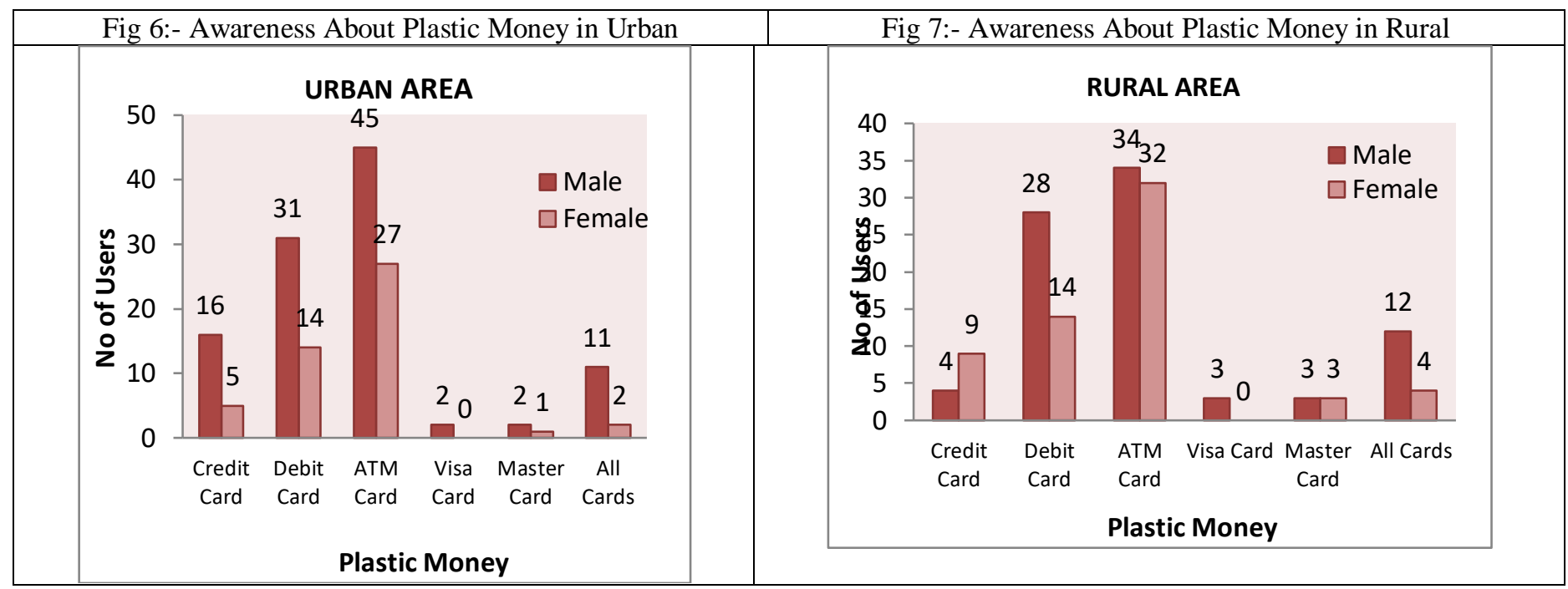

Monthly Transaction in Urban\& Rural Area:

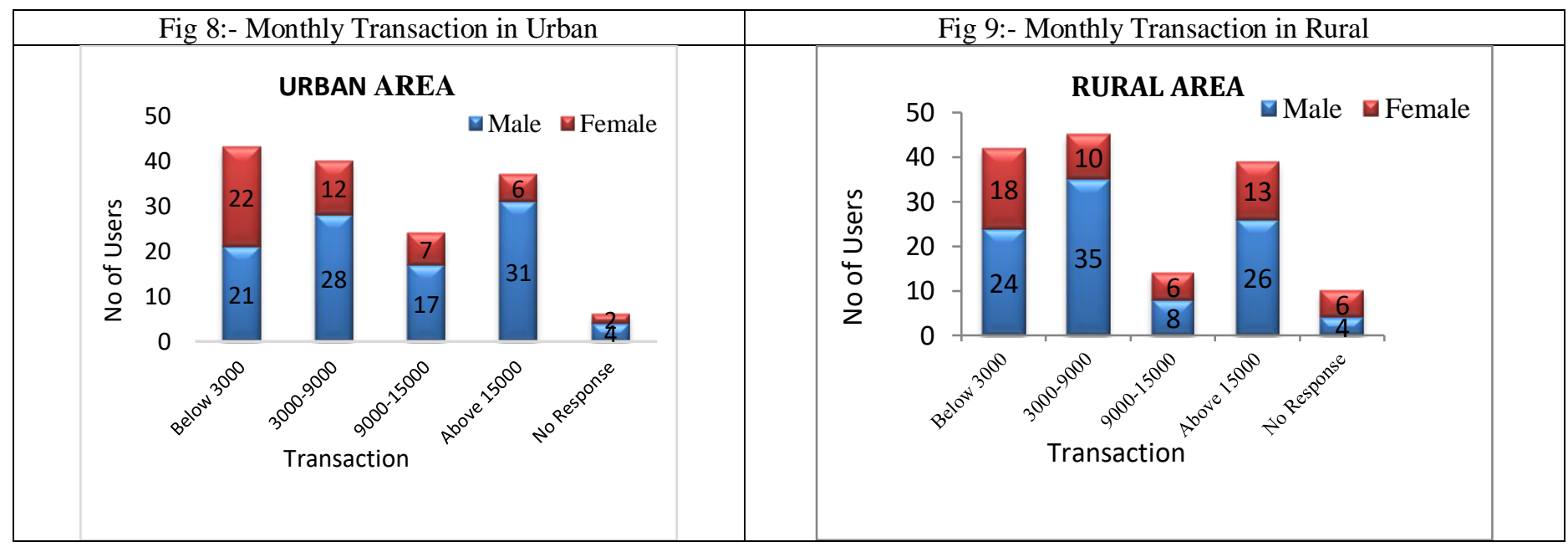

\begin{tabular}{|c|c|}
\hline \multicolumn{2}{|c|}{ Fig 10:- Effect of Demonetization on Online Banking in Ur } \\
\& Rural Area \\
\hline EFFECT OF DEMONETISATION \\
\\
$4 \%$
\end{tabular}

Fig 11:- Purposes for Use of Online Banking:

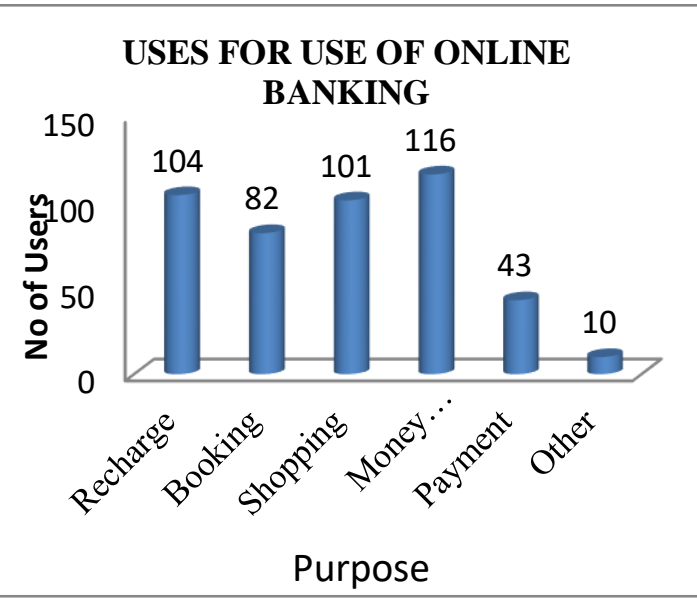




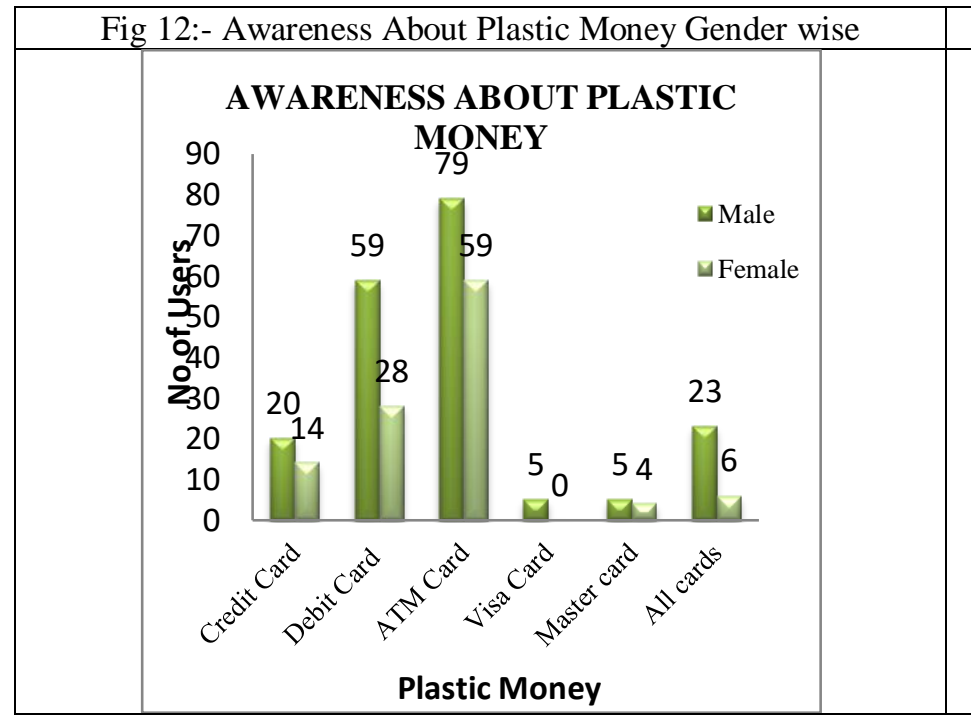

\section{Testing of hypothesis}

1. Chi square test for independence between sex and online banking users in urban area

$\mathrm{H}_{0}$ : online banking users are independent of sex in urban area

$\mathrm{H}_{1}$ : online banking users not independent of sex in urban area

$$
\chi_{\text {cal }}^{2}=0.2580 \quad \chi_{\text {tab }}^{2}=3.8410
$$

2. Chi square test for independence between sex and online banking users in rural area

$\mathrm{H}_{0}$ : online banking users are not independent of sex in rural area

$\mathrm{H}_{1}$ : online banking users are independent of sex in rural area

$$
\chi_{\text {cal }}^{2}=0.3807 \quad \chi_{t a b}^{2}=3.8410
$$

Fig 13:- Monthly Transaction

\section{MONTHLY TRANSACTION}

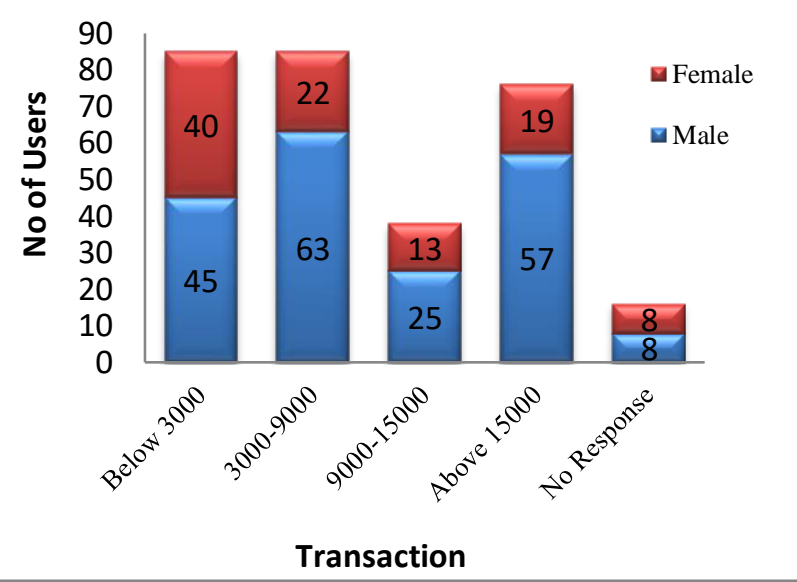

3. Proportion test for male in urban $\&$ rural area $\mathrm{H}_{0}: \mathrm{P}_{1}=\mathrm{P}_{2} \quad \mathrm{H}_{1}: \mathrm{P}_{1} \neq \mathrm{P}_{2}$

$$
Z_{\text {cal }}=0.8156 \quad Z_{\text {tab }}=1.96
$$

3. Proportion test for female in urban \& rural area Hypotheses are similar as above testing $Z_{\text {cal }}=$ $0.1358 Z_{t a b}=1.96$

4. Association and Colligation between online banking users and area

Coefficient of association $(Q)=-0.0682$

Coefficient of Colligation $(\mathrm{Y})=-0.0341$

5. Analysis of variance (ANOVA):

$\mathrm{H}_{11}$ : Average number of online banking users for Recharge, Booking, Shopping,

Money Transfer, Payment, Other are not equal

$\mathrm{H}_{12}$ : There is significant effect of area on number of online banking users

ANOVA TABLE

\begin{tabular}{|c|c|c|c|c|c|c|}
\hline Source of Variation & Sum of Squares & DF & Mean sum of squares & $F_{c a l}$ & P-value & $F_{\text {tab }}$ \\
\hline Online banking user & 4273.42 & 5 & 854.68 & 38.58 & 0.0005 & 5.050 \\
\hline Area & 168.75 & 1 & 168.75 & 7.61 & 0.0398 & 6.607 \\
\hline Error & 110.75 & 5 & 22.14 & & \\
\hline Total & 4552.92 & 11 & & & \\
\hline
\end{tabular}

Table 6

6. Analysis of variance (ANOVA):

$\mathrm{H}_{11}$ : Average number of online banking users of Bank App, Phone pay, Google pay, BHIM,

Paytm is not equal

$\mathrm{H}_{12}$ : There is significant effect of area on number of application type for online banking users

ANOVA TABLE

\begin{tabular}{|c|c|c|c|c|c|c|}
\hline Source of Variation & Sum of Squares & DF & Mean sum of squares & $F_{c a l}$ & P-value & $F_{\text {tab }}$ \\
\hline Online banking user & 1840.4 & 4 & 460.1 & 2.6765 & 0.1816 & 0.1816 \\
\hline Area & 32.4 & 1 & 32.4 & 0.1884 & 0.6865 & 0.6865 \\
\hline Error & 687.6 & 4 & 171.9 & & \\
\hline Total & 2560.4 & 9 & & & \\
\hline
\end{tabular}




\section{Kolmogorov-Smirnov Test (K-S Test):}

$\mathrm{H}_{0}$ : There is no significance difference between monthly transactions of online banking users

in urban and rural area

$\mathrm{H}_{1}$ : There is significance difference between monthly transactions of online banking users in urban and rural area

$$
D_{c a l}=0.0399 D_{t a b}=0.0785
$$

\section{CONCLUDING REMARKS}

"When you expect an honest Government with no corruption and malpractices, you also have to be honest. Honesty is not one-way road" - Prime Minister Shri Narendra Modi.

The growth of the cashless transaction system is reaching new heights. People tend to move to cashless transactions. It is right to say that the cashless system is not only a requirement but also a need for the society. From our study we conclude that, most of the people are uses online banking before demonetization for money transfer and feel secured about it. The male users are more aware about plastic money than female for transaction. The online banking users and sex are independent in rural and urban area. The online banking users for recharge, booking, shopping, money transfer, payment, other is different. There is no significant effect of area on number of online banking users that is people in rural as well as urban uses online banking. The average number of online banking users of Bank App, Phone pay, Google pay, BHIM, Paytm is also different. There is no significant effect of area on number of application type for online banking users.

\section{REFERENCES}

[1]. Rao, Kavita, Mukherjee, Sacchidananda, Kumar, Sudhanshu, Sengupta, Tandon, Suranjali, Nayudu, Sri Hari, (2016). Demonetisation: Impact on the Econom,. NIPFP Working Paper Series, New Delhi, pp. $1-18$.

[2]. Chelladurai, $M$ and Sornaganesh, V. (2016). "Demonetization, Unified Payment Interface \& Cashless Economy". International Journal of Informative \& Futuristic Research, 4 (3), pp. 5654 5662.

[3]. Kaur, Manpreet. (2017). Emonetisation: Impact on Cashless Payment System". International Journal of Science, Technology and Management, 6 (1), pp. 144 $-149$.

[4]. Mukhopadhyay, Bappaditya. (2016). "Understanding Cashless Payments in India". Financial Innovation, 2, pp. 1 - 26, doi: 10.1186/s40854-016-0047-4.

[5]. Ramdurg Anil I, \& Bassavara C S. (2016). Demonetization: Redefining Indian Economy International Journal of Commerce and Management Research. 2 (12), pp. $07-12$. 